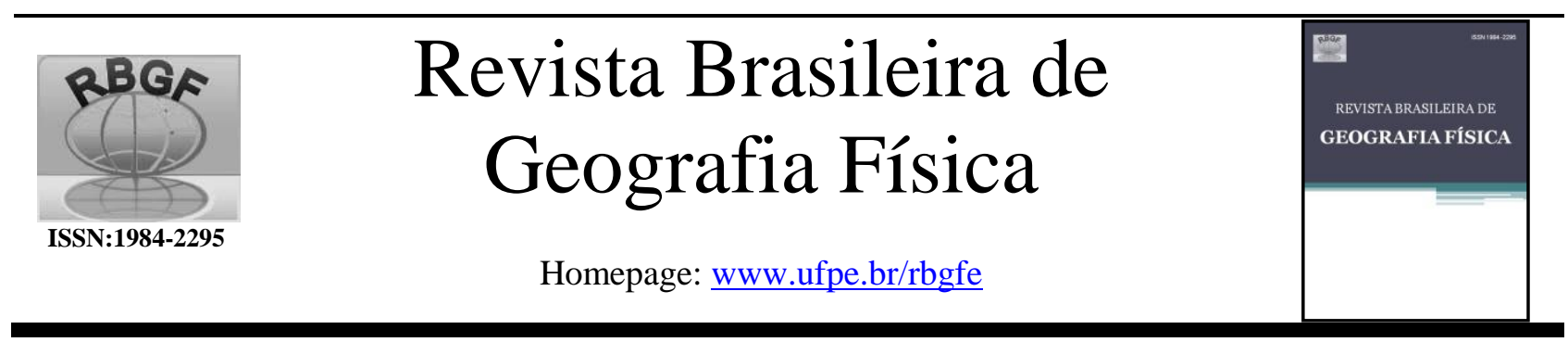

\title{
Simulation of changes in land use/land cover on wetlands through CA-Markov model
}

\author{
João Paulo Delapasse Simioni ${ }^{1}$, Laurindo Antonio Guasselli ${ }^{2}$,
}

\begin{abstract}
${ }^{1}$ Mestre em Geografia, Doutorando em Sensoriamento Remoto, Centro Estadual de Pesquisas em Sensoriamento Remoto e Meteorologia, Universidade Federal do Rio Grande do Sul. Av. Bento Gonçalves, 9500, Prédio 44202, Bairro Agronomia, CEP 91501-970 Porto Alegre RS. (55) 99999-0910. joao.delapasse@ufrgs.br (autor correspondente). ${ }^{2}$ Dr. em Recursos Hídricos e Saneamento Ambiental. Professor Associado do Dep. de Geografia, do Instituto de Geociências e professor do Programa de Pós-Graduação em Geografia e do Pós-Graduação em Sensoriamento Remoto da Universidade Federal do Rio Grande do Sul. Av. Bento Gonçalves, 9500, Prédio 44202, Bairro Agronomia, CEP 91501-970 Porto Alegre RS. (51) $3308-6665$. laurindo.guasselli@ufrgs.br.
\end{abstract}

Artigo recebido em 22/05/2018 e aceito em 17/07/2018

A B S T R A C T

Land use/land cover modeling is extremely important to land planners, since it allows creating projects and scenarios with possible future threats to ecosystems. Thus, the aim of the present study was to apply the CA-Marvok model to simulate the land use and land cover for the year 2030 in the environmental protection area of the Banhado Grande (EPABG), Brazil. Thus, two images Landsat 5 TM and 8 OLI from 2007 and 2017 were classified. The CA-Markov model was applied through the Land Change Modeler (LCM) tool of the TerrSet software. The results show that the soybean class was the one that most grew between 2007 and 2017, going from 5,891 to 33,844 ha. The simulation shows that 45,375 ha of soybeans will be cultivated at EPABG by 2030, replacing mainly floodplain areas and wetlands (WL's). In view of the above, it is concluded that the simulation of land use land cover for 2030 showed that soybean cultivated area will correspond to approximately $33 \%$ of land use and land cover in EPABG. Therefore, it is recommended to create the EPABG management plan focused on the maintenance of the biodiversity and wetlands of the EPABG.

Keywords: Modeling, Remote sensing, Wetlands.

\section{Simulação das mudanças no uso e cobertura da terra em áreas úmidas através do modelo CA-} Markov

\section{R E S U M O}

A modelagem do uso e cobertura da terra é de vital importância para os planejadores do território, pois permite a criação de projetos e cenários com possíveis ameaças futuras aos ecossistemas. Assim, o objetivo deste trabalho é aplicar o modelo CA-Marvok para simular o uso e cobertura da terra para o ano de 2030, na Área de Proteção Ambiental do Banhado Grande (EPABG), Brasil. Para isto, foram classificadas duas imagens Landsat 5 TM e 8 OLI de 2007 e 2017. O modelo de CA-Markov foi aplicado através da ferramenta Land Change Modeler (LCM) do software TerrSet. Os resultados mostram que a classe de soja foi a que mais cresceu entre 2007 e 2017, passando de 5.891 ha para 33.844. A simulação mostra que para 2030 serão cultivados na EPABG 45.375 ha de soja, substituindo principalmente áreas de várzeas e campos úmidos. Em vista disso, conclui-se que a simulação do uso e cobertura da terra para 2030 mostrou que a área cultivada de soja corresponderá à aprximadamente 33\% do uso e cobertura da terra na EPABG. Assim, recomendase a criação do plano de manejo da EPABG, com vistas, principalmente, na manutenção da biodiversidade e também das áreas úmidas da EPABG.

Palavras-chave: Modelagem, Sensoriamento Remoto, Áreas Úmidas.

\section{Introdução}

The impacts caused by changes in land use are one of the main concerns regarding the environmental planning and management of protected areas (PAs) (Liu et al., 2017) .

For instance, advances in agricultural frontiers in PAs can be a threat to both biodiversity, with the introduction of monoculture, and traditional population, which ends up moving from areas of agricultural expansion to large cities mainly due to agricultural mechanization (Lathuilli Ere et al., 2017).

The Environmental Protection Area of the Banhado Grande (EPABG), located in the east region of the State of Rio Grande do Sul (RS), has 
historically suffered from environmental impacts resulting from agricultural activities (Simioni et al., 2017).

It is estimated that the insertion of rice growing in EPABG has started in the first half of the 1940s. However, the impacts were accelerated after 1980, through the Pro-Várzea Program of the Federal Government, when the National Department of Public Works and Sanitation (NDPWS) rectified $25 \mathrm{~km}$ of the Gravataí river channel with the purpose of draining the wetlands (WL's) for the insertion of rice growing (Leite and Guasselli, 2013).

Currently, EPABG faces environmental problems such as the expansion of the agricultural frontier over marshes, erosion of the Gravataí river channel, gully, emission of agrochemicals by agricultural activities, among others (Leite and Guasselli, 2013).

Despite the several environmental impacts caused by the rice growing activities in EPABG, regarding the cultivated areas, rice cultivation is still the best alternative to substitute wetlands, since they remain flooded for a great part of the time and are even considered as artificial wetlands (Rolon, 2013).

Since the 2000s, soybean production has gained increasing relevance in Brazil, especially in the states of Amazonas, Pará, Rio Grande do Sul, and Mato Grosso, the largest producer in the country (Lathuilli Ere et al., 2017).

In 2000/01 harvest, the State of Rio Grande do Sul produced 4.7 million tons of soybeans, which corresponded to around $14.3 \%$ of the national production (IBGE, 2017). In the 2016/17 harvest, this value increased to 18.2 million tons, corresponding to $35.8 \%$ of the national soybean production (IBGE, 2017).

The main factors responsible for the increase of soybean areas in the RS are the valorization in the international market, the reduced cost of production and the possibility of producing soybean in floodplain areas which were previously occupied only by rice (Phélinas and Choumert, 2017). Pinto et al. (2014) pointed out that soybean cultivation in floodplain areas has begun in RS in the 2010/11 harvest, and in the following harvest (2012/13) more than 250,000 ha soybean were grown in a floodplain area suitable for irrigated rice cultivation. This latter fact becomes a threat to wetlands since, unlike rice, the soybean does not need flood to be developed, which can decimate species such as fish, birds, reptiles and amphibians (Ballantine et al., 2017).

Based on the above, several models have been applied for simulating land use and land cover aiming to the planning and conservation. For instance, the Cellular Automaton (CA) and Markov chain models show great advantages in the study of land use changes. However, at the same time, both have limitations with respect to their application, and can be improved through the integration of both models (Subedi et al., 2013). Thus, the CAMarkov model is able to absorb the benefits of the time series and spatial predictions of Markov and CA theories, and can be used successfully to simulate the land use/land cover (LULC) pattern (Halmy et al., 2015).

Several studies have applied the CAMarkov model for further LULC simulation. Halmy et al. (2015) analyzed the change in land use/land cover in Egypt; Romano et al. (2018) modeled potential land use changes based on the Land Change Modeler (LCM) and Etemadi et al. (2018) used the CA-Markov to assess the changes of LULC in mangroves in Iran.

Thus, the aim of the present study was to apply the CA-Markov model to simulate land use/land cover changes, based on the insertion of soybean in floodplain areas on the EPABG wetlands.

\section{Material and methods}

Study area

The study was performed in the Environmental Protection Area of Banhado Grande, located in the Gravataí River Basin, Brazil. The EPABG has an area of 136,935 ha (Figure 01) and is considered one of the most important wetlands of the RS. Its biodiversity is known due to the large variety of birds, especially migratory ones, considered by experts as of relevance for global conservation (Simioni et al., 2017).

The EPABG has an extensive composition of WLs, formed by the marshes Banhado Grande, Banhado dos Pachecos, and the floodplain of the Gravataí River. This area is called the Banhado Grande System (BGS). The BGS is delimited by the elevation of $20 \mathrm{~m}$, composed by a continuous area of swamps or marshes, flood plains, and rice paddies. 
When performing a study on the flood pulses in the APABG, Simioni et al. (2017) verified that when the rainfall is greater than $247 \mathrm{~mm}$ in approximately 30 days, a connectivity among the EPABG wetlands is established, interconnecting the diverse compartments of the BGS. Such connectivity is responsible for several interactions among these wetlands, such as exchange of nutrients, sediments and organisms.

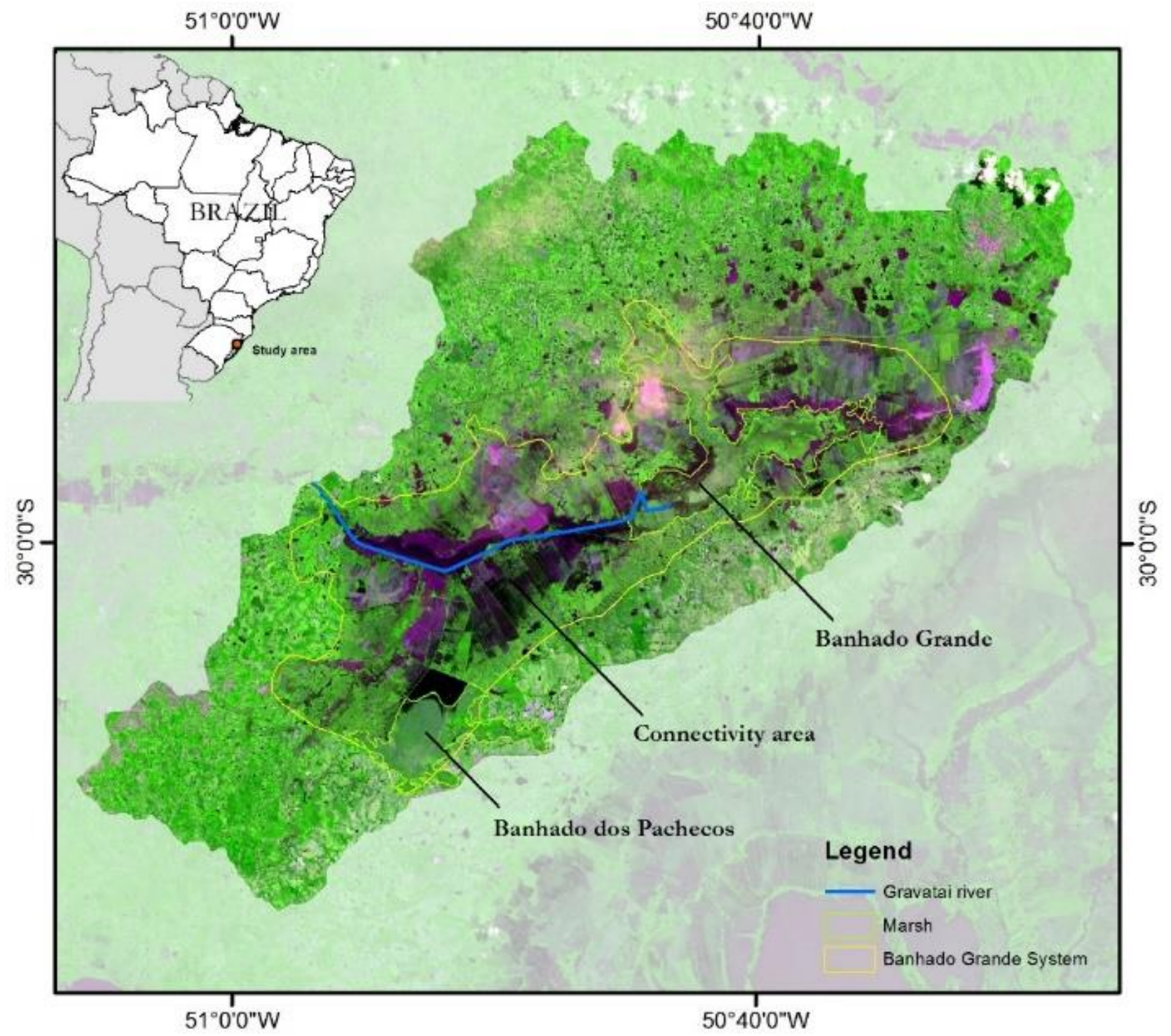

Figure 01. Location of the Environmental Protection Area of Banhado Grande (EPABG), Brazil.

Although rainfall averages show a monthly pattern with little rainfall variation (Figure 02), the standard deviation values show the unpredictability of flood and dry pulses. In months such as March, June, October and November, the standard deviation varies between 83 and $114 \mathrm{~mm}$, making the eventuality of pulses a major characteristic of wetlands from the State of Rio Grande do Sul when compared to the rest of the country.
With regard to the climate, the annual average temperature varies between 17 and $20^{\circ} \mathrm{C}$, with a rainfall regime between 1,700 and $1,800 \mathrm{~mm}$ per year. The average monthly rainfall ranges from $100 \mathrm{~mm}$ in the least rainy months (February, April, June, July, August, and December) to $150 \mathrm{~mm}$ in the months of highest rainfall (March and October). 


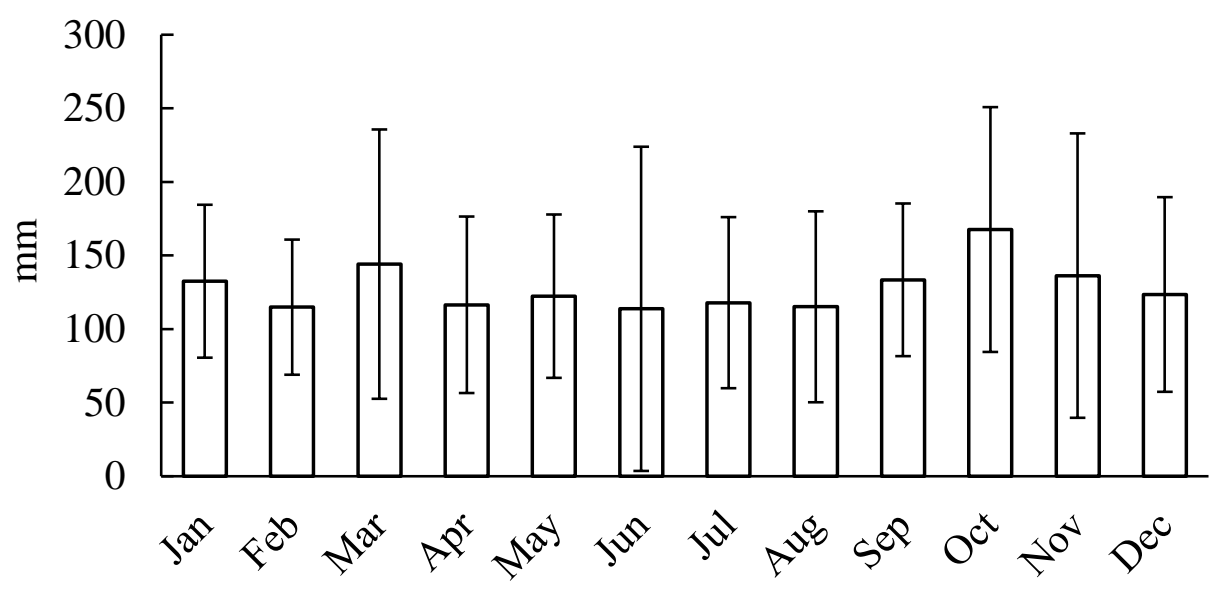

Figure 02. Average monthly rainfall in the Environmental Protection Area of Banhado Grande (APABG), between 1991 and 2017.

The dates were chosen according to the rice and soybean growth phase in RS. The atmospheric correction was performed only in the image from Landsat $5 \mathrm{TM}$, since the Landsat 8 OLI image has already been atmospherically corrected.

For the classification, the segmentation method was used, dividing the image into a set of contiguous pixels which are spread bidirectionally with uniformity. This division consists of a process of region growth and edge detection. No native forests were differentiated from exotic ones.

Thus, seven classes were defined concerning the main types of land use and occupation present in the EPABG, being rice crop, soybean crop, exposed soil, forest, aquatic macrophytes, urban area, and water.

The images were subjected to a maximum likelihood classification that considers the weighting of distances among averages of class pixels using statistical parameters.

\section{CA-Markov Model}

The simulation of land use and land cover was performed with the CA-Markov model. The CA-Markov is capable to simulate changes in land use among various categories and combines CA and Markov procedures (Romano et al., 2018). The Markov chain is a stochastic model based on the transition probability. By itself, this model does not take into account the causes of changes in land use and is insensitive to space (Ricobom and Caneparo, 2017).

The Markov model considers the conversion from one class to another (class transition) (Kumar et al., 2014). Being $P$ the transition probability of the current class in another class next time, the expression is as follows:

$$
P=P_{i j}\left|\begin{array}{ccccc}
P_{11} & P_{12} P_{13} & \ldots & P_{1 n} \\
P_{21} P_{22} P_{23} & \ldots & P_{2 n} \\
\ldots & \ldots & \ldots & \ldots & \ldots \\
P_{n 1} P_{n 2} & P_{n 3} & \ldots & P_{n n}
\end{array}\right|
$$

Where: $P$ is the transition probability from $i$ class to $j$ class. The key step of the Markov model consists of obtaining a primary matrix and a transition probability matrix $(P i j)$. Thus, the Markov prediction model is

$P_{(n)}=P_{(n-1)} \quad P_{i j}=P_{(0)} P_{i j}^{n}$

The cellular automaton (CA) model can be stochastic, deterministic or mixed. The CA is concerned with spatialization, since it simulates processes of change or spatial growth of a system, based on the premise that the future state a class will assume is the present state of its neighboring classes (Ricobom and Caneparo, 2017).

Thus, the CA model uses not only the previous state information of land cover, such as the one performed by the Markov model, but also uses the state of neighboring classes for their transition rules (Adhikari and Southworth, 2012).

The CA-Markov consists of passing a $5 \mathrm{x}$ 5 Boolean filter over each pixel of the simulated LULC to 2030, implementing a spatial weight factor among neighboring pixels. The highest weights will be attributed to the pixels representing an area which matches most closely the current land use and land cover (Ricobom and Caneparo, 2017).

For this reason, the spatial modeling technique through integration of the Markov model and the CA is considered one of the best options for the LULC analysis in different spatial scales (Rimal et al., 2017). In Figure 03 is shown the flowchart of application of the CA-Markov model. 


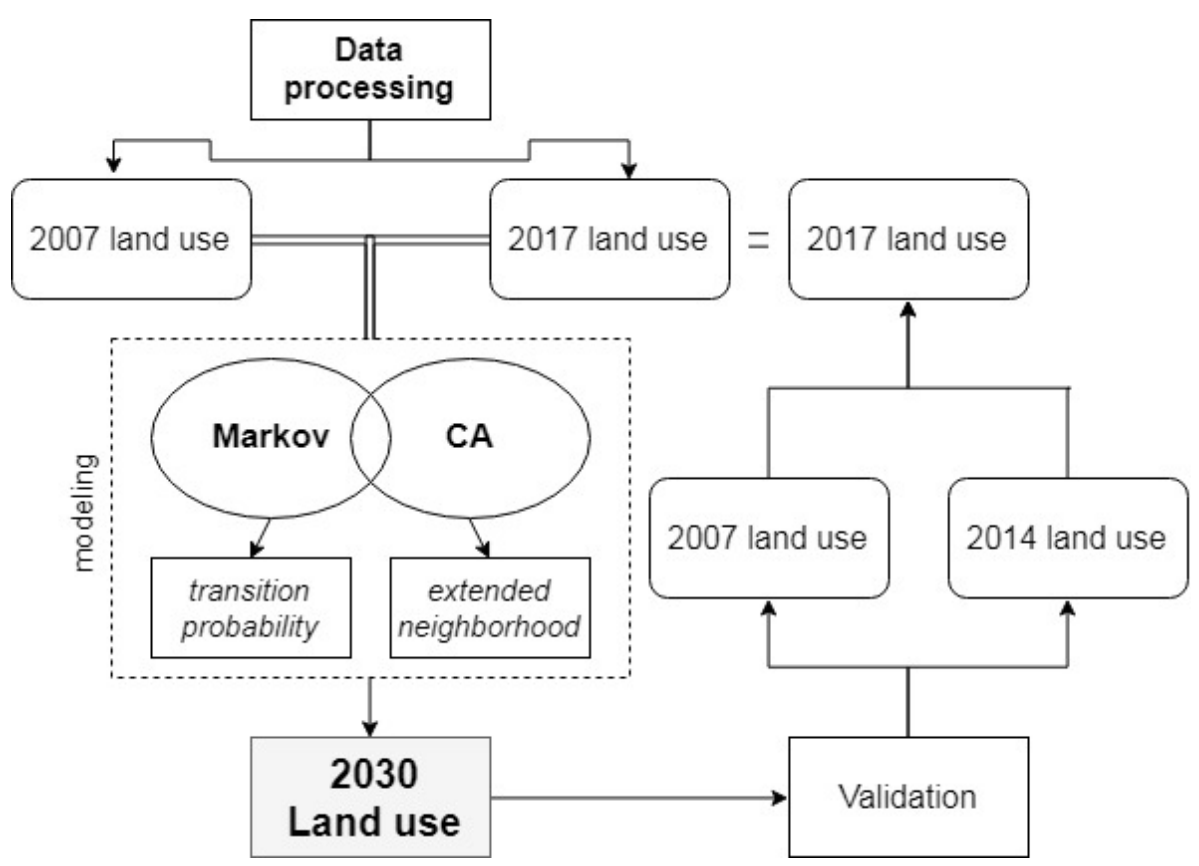

Figure 03. Flowchart of application of the CA-Markov model.

Besides the CA-Markov model, the following components of the TerrSet software were used in the study:

Land Change Analysis: where two historical land use and land cover images (2007 and 2017) were compared in order to verify the gains and losses of each class within the period;

Transition Potential Modeling: where the transition potential of the classes fields, rice, soil, and forest were analyzed for the soybean class; the transition potential was performed using a modified KNN (K-nearest neighbors) and a multilayered neural network. The following variables were used in the model: i) elevation (Shuttle Radar Topography Mission - SRTM), since the rice and soybean areas are cultivated in slopes of up to $20 \%$; ii) road network, respecting the domain ranges, from $16 \mathrm{~m}$ to highways and $11 \mathrm{~m}$ to secondary roads; iii) water resources and their respective Permanent Preservation Areas (PPAs), which must be kept untouched by law.

\section{Validation}

The LULC was performed using the methodology by Memarian et al. (2012), which validated the Markov chain for LULC simulation in the Langat basin, Malaysia. To this end, the LULC was simulated for the year 2017 using the images dated from 2007 (previously used) and Landsat 8 OLI obtained on 2/2/2014. As the 2017 image had been classified previously, the 2017 classification was attributed as field truth and the CA-Markov model was applied again, but this time using the images from 2007 and 2014. Kappa coefficient was used to validate the model, describing and testing the degree of agreement (reliability and accuracy) in the classification, equation 3:

$k=\frac{p_{o}-p_{e}}{1-p_{e}}$

Where:

$$
\begin{aligned}
& p_{o}=\text { real area; } \\
& p_{e}=\text { area estimated by the CA-Markov model; }
\end{aligned}
$$

\section{Results}

In Figure 04 is shown the gains and losses between 2007 and 2017. It is noted that marshes and field areas presented the greatest losses between the analyzed years, with a deficit of approximately 30,000 ha. Regarding the gains, it is verified that the areas with soybean cultivation showed the highest increase, reaching 30,000 ha in 2017 , suggesting that the areas occupied by fields and macrophytes in 2007 were replaced by soybean cultivation in 2017.

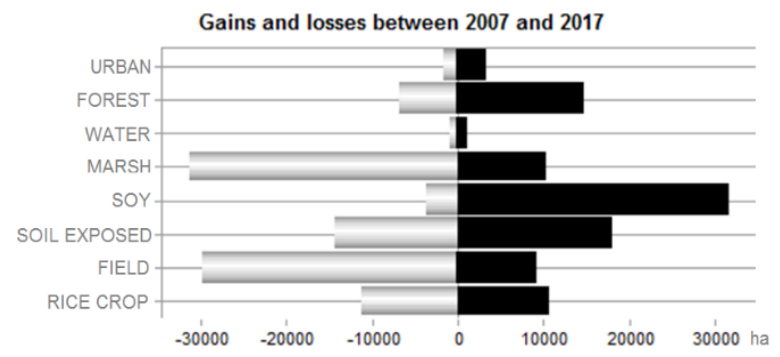

Figure 04. Gains and losses between 2007 and 2017.

The comparison between the LULC in the 2007 and 2017 images shows that soybean class 
showed the highest increase in EPABG, going from approximately 5,000 ha in 2007 to over 33,000 ha in 2017. In relation to the projection for 2030, soybean was also the class that showed the highest growth, reaching 45,000 ha, mainly due to substitution of field areas (Figure 05).

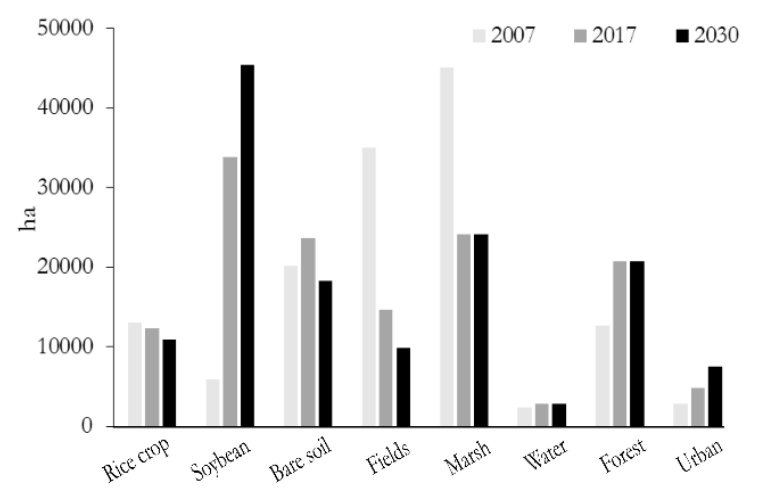

Figure 05. Class areas in 2007, 2017, and 2030 (simulation).

Rice cultivation showed little variation over the years and tend to decline by 2030 . The marsh areas showed a significant decrease between 2007 and 2017, going from 48,000 ha to 24,000 ha. However, these areas are considered as PPAs by the State of Rio Grande do Sul.
Therefore, whether there is compliance with the law and greater inspection, the marsh areas tend to remain as they are until 2030.

In Figure 06 is shown the switching potential from other classes to soybean. The area with the greatest transition from other classes to soybean is located to the north in the EPABG, close to the border with the Banhado Grande, where the potential for change was $40 \%$. It is also noteworthy that the central part of the EPABG presented a transition potential from other classes to soybean of up to $33 \%$ between 2007 and 2017.

In Figure 07 is shown the land use mapping for 2007, 2017, and the modeling for 2030. In 2007, EPABG predominated mainly in field areas (undergrowth) and areas with rice cultivation, which were mainly concentrated in the central portion of the EPABG, where there is connectivity, and to the north of Banhado Grande.

For the 2017 image, it is observed that the rice cultivation in the EPABG is located mainly in the connectivity area and in the northern part of the Banhado Brande. Additionally, it is noted that field areas were converted to soybean, especially in the northern portion of the EPABG.

\section{areas changed for soybean between 2007 and 2017}

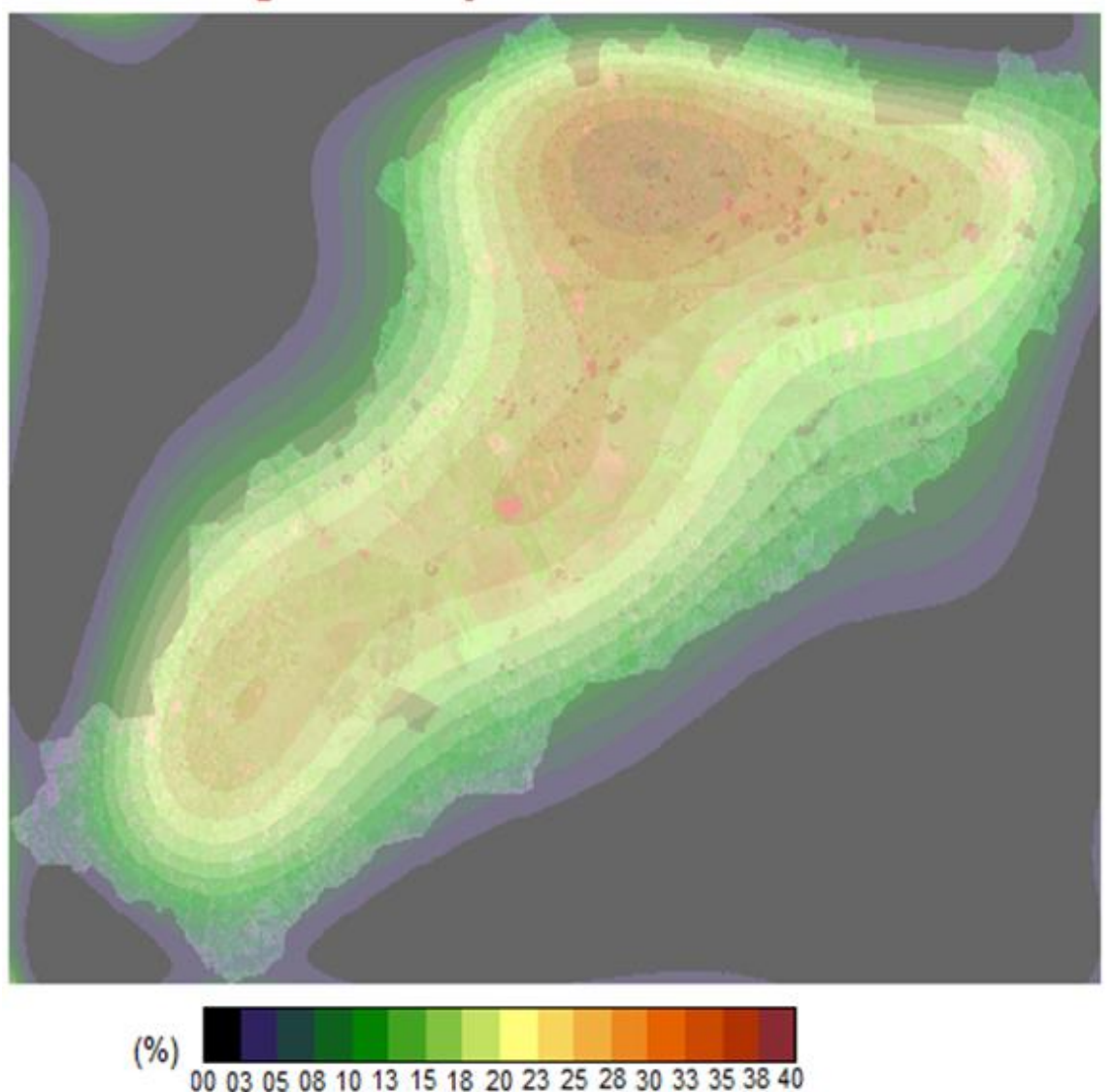

Figure 06. Areas that have changed from other classes to soybean. 


\section{Land use in \\ 03/02/2007}

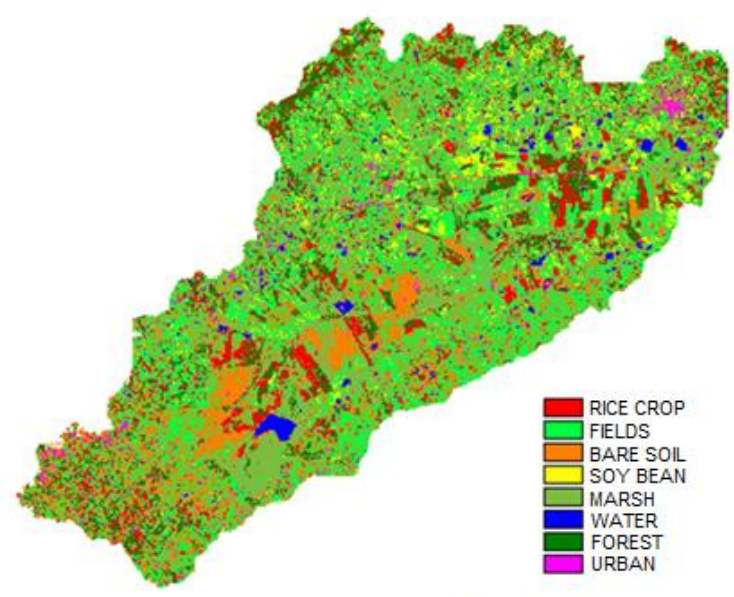

Projection for 2030

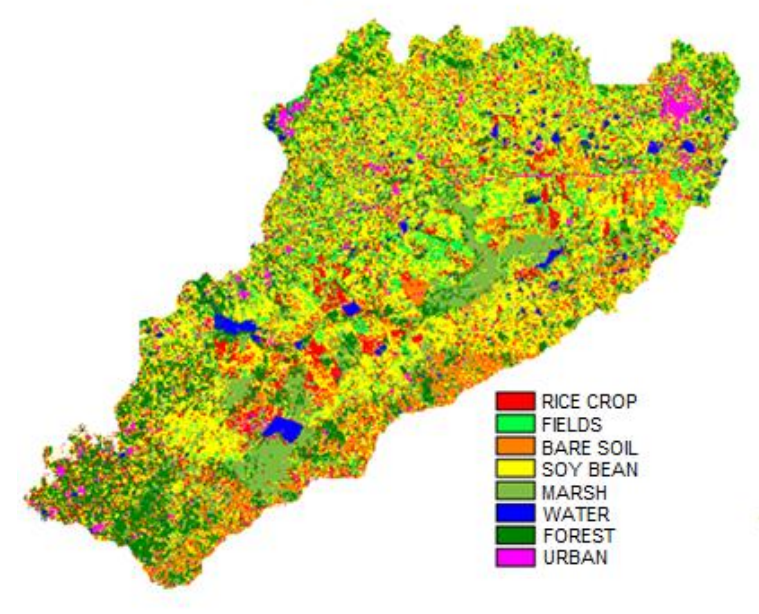

Land use in 02/03/2017

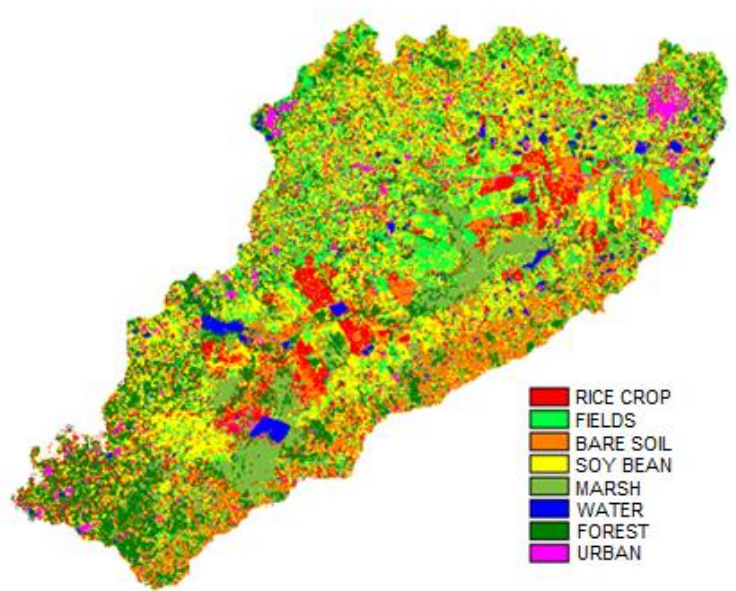

Potential areas for change to 2030

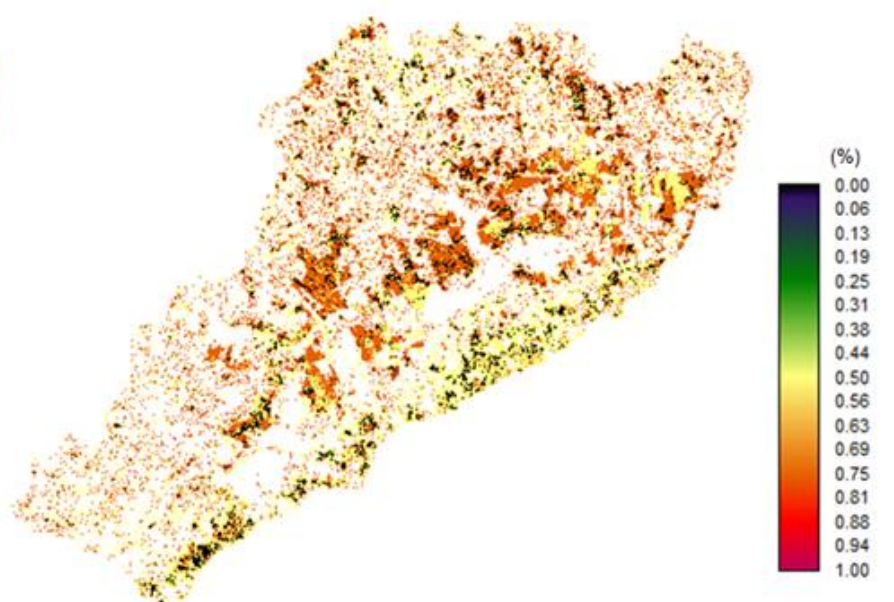

Figure 07. Land use in 2007, 2017 and the projection for 2030 with the potential areas for transition.

The projection for 2030 based on the CAMarkov shows the fixation of soybean cultivation in the connectivity area between the Banhado Grande, Banhado dos Pachecos and the floodplain of the Gravataí River. In addition, soybean predominates in northern areas of the EPABG. Although the wetlands are protected by law, it is projected to 2030 that the soybean insertion will reach the limits of the Banhado Grande and Banhado dos Pachecos.

Regarding the potential areas for land use transition, the areas close to the Banhado Grande show the greatest potential for change, with a probability of up to $75 \%$ change. It can be observed that these areas are located largely in the limits with the Banhado Grande, which can compress the wetland areas, thus threatening the biodiversity of these areas.
Validation

The validation presented a kappa of 0.84 agreement between the areas of classes referring to the classification of the 2017 image and the projection for 2017 from the CA-Markov. Soybean showed the highest error among the images (Figure 08), approximately 6,000 ha, which may be related to the rapid growth of soybean production in 2017 in relation to previous years, thus being underestimated by the model.

The classes of water, forest and urban areas showed the highest similarities between the classified image and the CA-Markov model. 


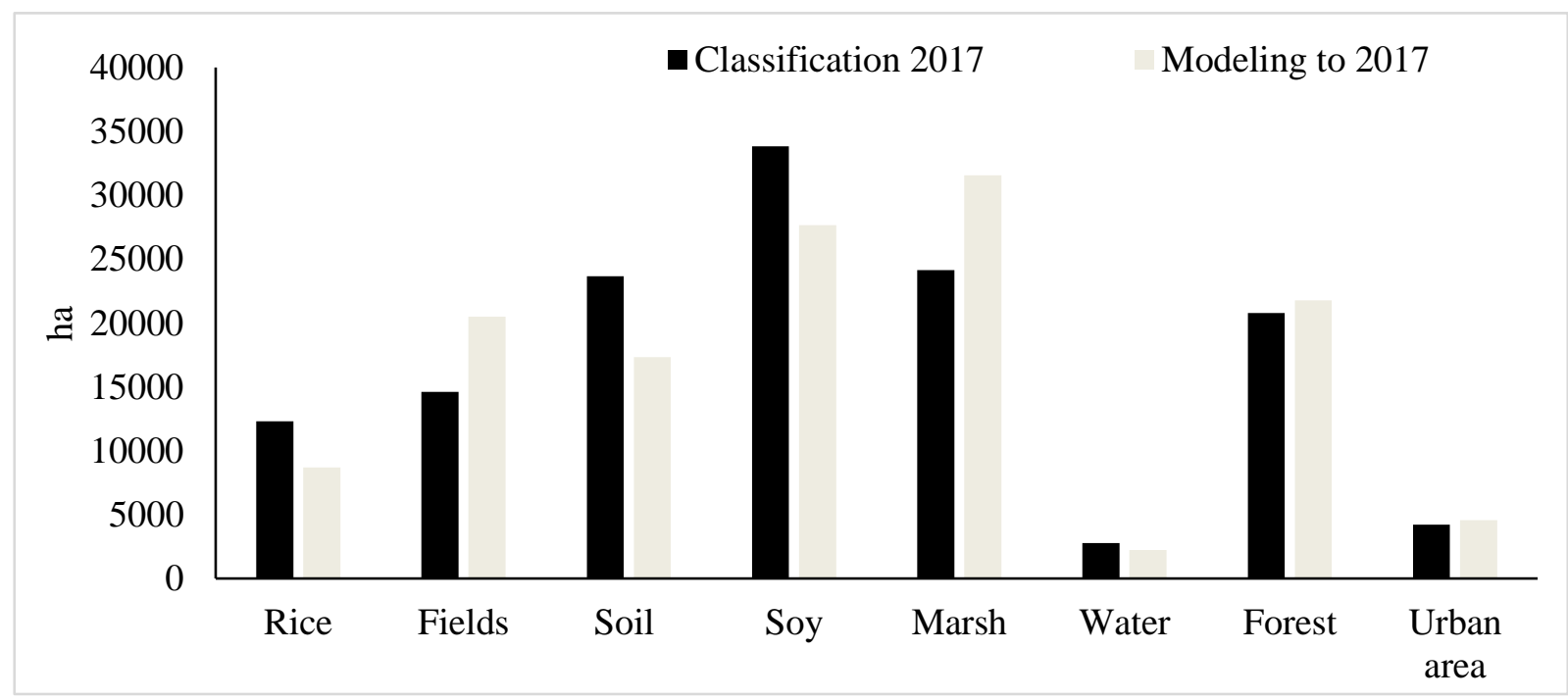

Figure 08. Comparison between the classified image and the simulation from the CA-Markov.

\section{Discussion}

The use of mathematical models for projections of land use and occupation in future scenarios is a fundamental tool for territory planners and managers, since it allows understanding the dynamics of human activities as well as the main threats to which the ecosystem will be subjected (Lathuilli Ere et al., 2017).

Halmy et al. (2015) treats modeling as a promising practice for the understanding of land use and occupation patterns, considering as an essential tool for environmental planning and management.

The importance of remote sensing for mapping and monitoring changes in land use and land cover was discussed by Almeida et al. (2015). According to the authors, the possibility of acquiring data on large geographic extensions at increasingly smaller time scales allows a better understanding of processes occurring in these areas.

The CA-Markov model allows addressing issues of how the LULC will be in the EPABG hereafter whether planning measures are not taken (Adhikari and Southworth, 2012). Although considered as a PA, the lack of a management plan makes the agricultural activities within the EPABG continue to progress rapidly, jeopardizing the marsh areas and the biodiversity present in the APABG.

Boerema et al. (2016) points out that the expansion of soybean cultivation occurred mainly in field areas, moving livestock to other forested areas. However, in recent years, soybean cultivation has also shifted livestock to uncultivated ecosystems, including wetlands such as EPABG.
The presence of soybeans and rice is also observed in the central part of the EPABG, in the floodplain of the Gravataí River. Simioni et al. (2017) emphasize the importance of preserving this area, which forms a connectivity between the Banhado Grande and Banhado dos Pachecos and the floodplain of the Gravataí River during great floods.

Silva (2016) analyzed the dynamics of the environmental fragility in EPABG and pointed out that rice and soybean cultivation contribute to the re lease of organic matter from fertilizers, generating different environmental impacts on water resources.

The impacts of agricultural cultivation on EPABG go beyond water resources. According Silva (2016), these impacts also affect biodiversity, with the insertion of monoculture; soil degradation and erosion, and the population that enjoys these resources directly, both in fishing and recreation, as well as in water consumption.

The CA-Markov model shows that the cultivation of soybean in lowlands is a potential threat to the EPABG wetlands, since this crop does not require permanent irrigation, similarly as rice. This fact can result in a significant loss of biodiversity present in wetlands, because unlike soybeans, irrigated rice cultivation is able to maintain a portion of the biota during cultivation, such as birds, fish and reptiles (Rolon, 2013).

\section{Final considerations}

The LULC simulation proved to be an effective tool in the planning and management of wetlands. Simultaneously, the data showed threatening results for the EPABG wetlands 
whether the same LULC dynamics were maintained by 2030 .

The performance of the Markov-CA model in the LULC prediction for 2030 reveals the potential and worthiness of using this approach to design future land use changes, especially from the insertion of soybeans into wetlands. The distribution of the simulated potential of the LULC classes indicates that the changes experienced by the EPABG in recent years are likely to continue.

The present study aims to assist in the decision making regarding the management plan of the EPABG in progress. Furthermore, producers' awareness are also expected, besides greater oversight by government agencies on agricultural crops, especially soybeans, in swamp areas which are considered as PPAs, according to RS legislation.

Moreover, it is recommended, in relation to the WLs of Rio Grande do Sul, the creation of a specific legislation, dealing with the classification and design of these areas of high productivity and ecological value. Furthermore, the State also lacks public policies aimed at the conservation of wetlands, which although they appear as PPAs in the legislation, there is not a clear definition of how to delimit these areas. Besides vegetation, soils and geology can be important tools in helping to design these wetlands.

\section{Acknowledgment}

The authors thank Coordenação de Aperfeiçoamento de Pessoal de Nível Superior (CAPES) for João Paulo Delapasse Simioni doctoral fellowships in the Remote Sensing and Meteorological State Center (CEPSRM) at the Rio Grande do Sul Federal University (UFRGS), for the support provided during this research.

\section{References}

Adhikari, S., Southworth, J., 2012. Simulating Forest Cover Changes of Bannerghatta National Park Based on a CA-Markov Model: A Remote Sensing Approach. Remote Sens 4, 3215-3243. doi: 10.3390/rs4103215.

Almeida, J.S., Melo, W.F., Andrade, A.B.A., Saldanha, H.G.A.C., Rodrigues, L.M.S., 2015. Modeling of the use of dynamic and land occupation in the municipality of Pombal - PB. Rev Verde Agroecol e Desenvolv Sustentável 10, 276-282. doi: http://dx.doi.org/10.18378/rvads.v10i1.3923.

Ballantine, K.A., Anderson, T.R., Pierce, E.A., Groffman, P.M., 2017. Restoration of denitrification in agricultural wetlands. Ecol
Eng 106, 570-577. doi: 10.1016/j.ecoleng.2017.06.033.

Boerema, A., Peeters, A., Swolfs, S., Vandevenne, F., Jacobs, S.S., Jan Meire, P., 2016. Soybean Trade: Balancing Environmental and SocioEconomic Impacts of an Intercontinental Market. PLoS One 11, 155222. doi: 10.1371/journal.pone.0155222.

Etemadi, H., Smoak, J.M., Karami, J., 2018. Land use change assessment in coastal mangrove forests of Iran utilizing satellite imagery and CA-Markov algorithms to monitor and predict future change. Environ Earth Sci 77, 1-13. doi: 10.1007/s12665-018-7392-8.

Halmy, M.W.A., Gessler, P.E., Hicke, J.A., Salem, B.B., 2015. Land use/land cover change detection and prediction in the north-western coastal desert of Egypt using Markov-CA. Appl Geogr 63, 101-112. doi: 10.1016/J.APGEOG.2015.06.015.

IBGE, Instituto Brasileiro de Geografia e Estatística, 2017. Sistema IBGE de Recuperação Automática - SIDRA. Available in:www.sidra.ibge.gov.br/home/ipca15/brasi 1. Accessed 28 Mar 2018.

Kumar, S., Radhakrishnan, N., Mathew, S. 2014. Land use change modelling using a Markov model and remote sensing. Geomatics, Nat Hazards Risk 5, 145-156. doi: 10.1080/19475705.2013.795502.

Lathuilli Ere, M.J., Miranda, E.J., Ecile, B.C., Couto, E.G.J., Mark, S., 2017. Land occupation and transformation impacts of soybean production in Southern Amazonia, Brazil. Journal of Cleaner Production 149, 680-689. doi: 10.1016/j.jclepro.2017.02.120.

Leite, M.G., Guasselli, L.A. 2013. Spatio-temporal dynamics of aquatic macrophytes in Banhado Grande, Gravataí River basin. Para Onde!? 7, $17-24$.

Liu, X., Liang, X., Li, X., Xu, X.O., Jinpei, C., Yimin, L., Shaoying, W., Shaojian, P.F., 2017. A future land use simulation model (FLUS) for simulating multiple land use scenarios by coupling human and natural effects. Landsc Urban Plan 168, 94-116. doi: 10.1016/J.LANDURBPLAN.2017.09.019.

Memarian, H., Kumar, B.S., Bin, T.J., Teh Boon, S., Sood, C.H., Karim, A.K., 2012. Validation of CA-Markov for Simulation of Land Use and Cover Change in the Langat Basin, Malaysia. J Geogr Inf Syst 04, 542-554. doi: 10.4236/jgis.2012.46059.

Phélinas, P., Choumert, J., 2017. Is GM Soybean Cultivation in Argentina Sustainable? World Dev 99, 452-462. doi: 10.1016/J.WORLDDEV.2017.05.033. 
Pinto, F.F., Balardin, R., Debortoli, M., Madalosso, M., 2014. Desempenho de cultivares de soja em áreas de várzeas. Rev. Cultiv. Gd. Cult. (online), available in: www.grupocultivar.com.br/artigos/desempe nho-de-cultivares-de-soja-em-areas-devarzeas. Accessed 4 Apr 2018.

Ricobom, A.E., Caneparo, S.C., 2017. Methodology for generating predictive mappings using the Markov chain and cellular automata - pilot area: urban perimeter of Paranaguá - Paraná - Brazil. Geomathic 3, 300-308.

Rimal, B., Zhang, L., Keshtkar. H., 2017. Monitoring and Modeling of Spatiotemporal Urban Expansion and Land-Use/Land-Cover Change Using Integrated Markov Chain Cellular Automata Model. ISPRS Int J GeoInformation 6, 288-298. doi: 10.3390/ijgi6090288.

Rolon, A.S., 2013. Áreas úmidas artificiais - As lavouras de arroz no Rio Grande do Sul. Humanit - IHU On-Line 433:1-12. Available in:

http://www.ihuonline.unisinos.br/artigo/529

4-ana-silvia-rolon. Accessed 4 Apr 2018.
Romano, G., Abdelwahab, O.M.M., Gentile, F., 2018. Modeling land use changes and their impact on sediment load in a Mediterranean watershed. Catena 163, 342-353. doi: 10.1016/J.CATENA.2017.12.039.

Silva, R.C., 2016. Estudo da dinâmica da fragilidade ambiental na Bacia Hidrográfica do Rio Gravataí, RS. Tese (Doutorado) Universidade Federal da Bahia.

Simioni J.P.D., Guasselli, L.A., Etchelar, C.B., 2017. Connectivity among Wetlands of EPA of Banhado Grande, RS. Brazilian J Water Resour 22. doi: 10.1590/23180331.011716096.

Subedi, P., Subedi, K., Thapa, B., 2013. Application of a Hybrid Cellular Automaton - Markov (CA-Markov) Model in Land-Use Change Prediction: A Case Study of Saddle Creek Drainage Basin, Florida. Appl Ecol Environ Sci 1, 126-132. doi: 10.12691/aees1-6-5 